\section{The role of functionalized organic surfaces in metal biomineralization: insights from liquid-cell STEM experiments}

\author{
CHARLOTTE DEJEAN ${ }^{1}$, NATHALY ORTIZ PEÑ ${ }^{2}$, \\ DAMIEN ALLOYEAU ${ }^{2}$, BENEDICTE MENEZ ${ }^{1}$, CYRIL \\ GADAL $^{1}$ AND ALEXANDRE GELABERT ${ }^{1}$
}

${ }^{1}$ Université de Paris, Institut de physique du globe de Paris, CNRS UMR 7154

${ }^{2}$ Université de Paris, Laboratoire Matériaux et Phénomènes Quantiques, CNRS, 75013 Paris, France

Presenting Author: dejean@ipgp.fr

Direct observations under liquid conditions of mineral nucleation and growth on bacterial cells recently highlights, at the cell scale, the critical role of chemical functions carried by cell surfaces and exopolymers in metal biomineralization [1]. By taking advantage of liquid-cell scanning transmission electron microscopy (LC-STEM), and using the incident electron beam to provoke and observe the precipitation of Mn-bearing minerals, differences in the morphology and distribution of Mn precipitates were observed. They were related to differences in nucleation site density and accessibility on bacterial cell surfaces and exopolymers.

With the aim to better understand and characterize the role of the various chemical functions encountered on biological surfaces on Mn precipitation, we use here functionalized polystyrene beads of $1 \mu \mathrm{m}$ diameter as simple analogues of bacteria cells. Ten representative types of functionalization were selected for LC-STEM experiments, ranging from basic ones, like carboxylic groups $(-\mathrm{COOH})$ or amine functions $\left(-\mathrm{NH}_{2}\right)$, to chelating agents like nitrilotriacetic acid (NTA) or to protein compounds like streptavidin. This allows to characterize the specific impact of individual chemical function taken independently.

Manganese mineralization is observed for each type of functionalized beads, but with strong differences in growth rates and mineralization patterns. As illustrated in the figure, for the same electron dose rate, $\mathrm{Mn}$ precipitation for $\mathrm{COOH}$-bearing beads is much faster, compared to non-functionalized beads and, exhibit massive dendritic precipitates at the bead surface (see figure). Bulk measurements of electrophoretic mobility for each type of bead are used to tentatively correlate surface charge to mineral growth rate on beads. The bulk surface charge explains only partially $\mathrm{Mn}$ mineralization properties at the beads surface but other parameters like steric effect need to be explored.

[1] Couasnon, T., Alloyeau, D., Ménez, B., Guyot, F., Ghigo, J. M., \& Gélabert, A. (2020). In situ monitoring of exopolymerdependent $\mathrm{Mn}$ mineralization on bacterial surfaces. Science advances, 6(27), eaaz3125.

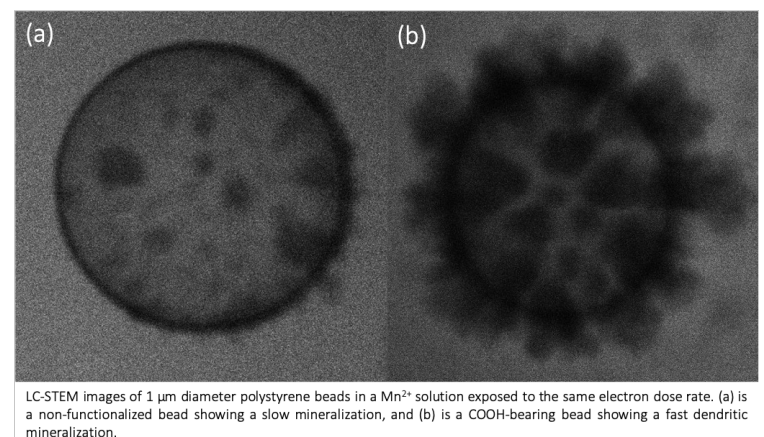
LC-STEM images of 1 um diameter polystyrene beads in a $\mathrm{Mn}^{2+}$ solution exposed to the same electron dose rate. (a) is
a non-functionalized bead showing a slow mineralization, and (b) is a cooH-bearing bead showing a fast dendritic
mineralization. 